\title{
Robot adoption and FDIs driven transformation in the automotive industry
}

\author{
Guendalina Anzolin ${ }^{1,2}$, Antonio Andreoni ${ }^{1}$ and Antonello Zanfei ${ }^{2}$ \\ ${ }^{1}$ Institute for Innovation and Public Purpose, University College London, UK \\ ${ }^{2}$ Department of Economics, Society and Politics, Università di Urbino, Italy
}

\begin{abstract}
This paper explores the relationship between inward Foreign Direct Investments and the adoption of industrial robots, across different segments of the automotive value chain. Using the International Federation of Robotics and fDiMarket datasets at a fine level of disaggregation of the automotive sector, we investigate the extent to which FDIs are related to the operational stock of industrial robots in 34 countries over the period 2005-2014. We find distinct patterns linking FDIs and robot adoption for different groups of countries and for different segments of the automotive value chain, that, is assembling and components production. With some relevant exceptions, FDIs are found to be highly correlated with robot adoption in the assembling segment across major leading countries. However, this correlation becomes weak for components production. To explain this differential role of FDIs in robot adoption, we formulate hypotheses around the country-specific drivers of robotisation for the components segment by pointing to the role of domestic ecosystems of suppliers and industrial policy as drivers of technology absorption and diffusion.
\end{abstract}

Keywords: automotive, industrial policy, fourth industrial revolution, industrial robots, global value chains, foreign direct investments

\section{Introduction}

During the last decade, the interest towards the alleged "fourth industrial revolution" has increased dramatically. A set of digital technologies are expected to have a profound impact on the international organisation of work and production, ultimately reshaping global value chains (OECD, 2017; UNIDO, 2017 and 2020). With a focus on robots in the automotive industry - i.e. a highly dynamic and transformative digital production technology with a relatively long history of application to the specific industry under observation - this paper investigates some of the potential drivers and mechanisms underlying the adoption of such production technology across different countries. Specifically, we focus on the actual and potential role of Foreign Direct Investments (FDIs) in technology adoption, and provide new evidence of the relationship linking number of FDIs received in a specific country and the operational stock of robots within the automotive sector. 
In developing our analysis, we refer to the broader literature regarding the relationship between FDIs and technological upgrading of recipient countries. Are FDIs a key driver of technology transfer and adoption? Under which circumstances di FDI have a positive effect on the technology absorption and diffusion in the domestic ecosystem of companies? Are FDIs enough to trigger the introduction of advanced technologies such as industrial robots? What is the role played by host country specific factors in the adoption and diffusion of industrial robots? What are the specific features of the automotive sector affecting these mechanisms?

Against this research agenda the paper will focus on the existence (or lack thereof) of a nexus between FDIs and the adoption of industrial robots in the automotive sector. We proceed in this direction by innovatively combining two datasets, the International Federation of Robotics (IFR) dataset, and fDi Markets dataset, supplied by fDi Intelligence, a specialised division of FT Ltd. We focus on the middle part of the automotive value chain, concerning manufacturing production processes. By combining descriptive statistics at different levels of analysis, we explore the extent to which FDIs are possibly driving the adoption of industrial robots and we formulate hypotheses on other complementary drivers and mechanisms. Specifically, taking advantage of the high level of data disaggregation and focusing on different segments of the automotive value chain - i.e. assembling and components production - we analyse the relationship between FDIs and patterns of robot adoption across 34 countries for two periods:

i) a ten-year period (2005-2014) with a data disaggregation distinguishing two segments of the industry - i.e. Automotive $\mathrm{OEM}^{1}$ and Automotive Components;

ii) a five-year period (2010-2014) considering four segments of the automotive value chain - i.e. ISIC Rev.4 Classes 2910 (motor vehicle assembling), 2931 (metal parts and plastics), 2933 (electric and electronic parts), 2939 (other parts which include seats, airbags, safety belts). This further level of disaggregation is only possible from 2010 due to data constraints.

Considering the cross-country heterogeneity in the patterns of robot adoption and the importance of domestic/regional value chains for technology diffusion, we formulate and explore a number of conjectures around the role of FDIs and additional country-specific factors that could act as drivers

\footnotetext{
${ }^{1}$ Original Equipment Manufacturer. The term generally refers to the original producer of components. In the automotive sector it is used as a synonym of car producing companies, i.e., the final assemblers.
} 
for robotisation. Special attention will be given to the potential role played in different countries by their domestic industrial ecosystem of suppliers and industrial policy incentives, that is, the extent to which a more or less developed domestic supply-chain and incentive packages can drive robots adoption and diffusion in the sector. We do so in the attempt to answer the main research question of the paper regarding the existence (or lack thereof) of correlation between FDIs and the increasing adoption of industrial robots at different segments of the automotive industry.

The paper is structured as follows. Section 2 presents a selective review of the literature on the relationship between FDIs and technical change, which we use to inform our research questions. We will consider both standard literature and more recent contributions which take into account global value chain mechanisms and local industrial policies, which are notably a crucial aspect of automotive sector dynamics. Section 3 considers the main features and trends that shaped the automotive sector in the last decades. Sections 4 and 5 present our sources of data and engage in a series of descriptive statistics to show different types of correlation (or absence thereof) between FDIs and robot adoption. Section 6 discusses our data and put forward some possible explanations based on alternative views on technological upgrading and industrialisation.

\section{Foreign Direct Investments and Technical Change}

A wide range of academic researchers have devoted their attention to the role of FDIs in stimulating growth and development. More specifically, the focus on technology spillovers and the associated learning opportunities have been increasingly covering an important part of the research on FDIs. Being the linchpin of this study on a specific production technology, e.g. industrial robots, and being the literature explicitly linking industrial robots and FDIs quite scant, we firstly engage in reviewing contributions on FDIs and technical change at a more general level. Since the 1980s, the role of FDIs and Multinational Corporations (MNCs) in promoting growth, employment, and economic diversification in emerging and developing countries has been widely debated. The literature and policy debates have recognised that FDIs can trigger productive transformation, however only to some extent and under specific conditions. Throughout the 1970s and 1980s, several concerns about the limited - and in some cases damaging - impact of MNCs and their FDIs in developing countries were raised, in particular with respect to their contribution to high quality industrialisation and technology transfer (Lall, 1978, 1979; Safarian, 1999). 
Over the 1980s and 1990s, the structural transformation experience of some of the late industrialisers softened these critical perspectives. First, positive experiences of productive, technological and organisational capabilities development started to emerge across a number of late industrialisers, especially in South and East Asia, in particular among those countries who developed a strategic engagement with MNCs (Wade, 1990; Amsden, 1989; for more recent contributions see Andreoni and Chang, 2019; Chang and Andreoni, 2020). This strategic engagement resulted in the establishment of joint ventures and increasing technology transfer, the absorption of global production technologies and standards, which led to the development of domestic supply chains through localisation policies alongside global value chain integration (Lall, 2000; Mpanju, 2012). Second, the accelerating pace of technological change (UNCTAD, 2018), together with the rising cost of innovation, contributed in viewing MNCs as a strategic asset, and often the only way to link up to new global waves of innovation and technologies.

Despite the rising role of MNCs and FDIs in emerging economies, the evidence of their impact on economic and technological upgrading of Least Developed Countries (LDCs) remains mixed, both in terms of technology absorption (through direct and indirect effects) and of technology diffusion. The next two sections review and unpack how technology absorption and diffusion have being analysed and supporting empirical evidence.

\subsection{Direct and Indirect Effects}

A standard distinction in the literature is between direct and indirect effects of FDIs on host economies (Zanfei, 2012; Castellani et al., 2015).

First, a substantial body of literature found a positive direct effect of inward FDIs on the host economies mainly in terms of: (i) changes in the composition of industry, as FDIs bring in bundles of competencies and knowledge assets that increase the overall productivity level of the recipient economy (Dunning, 1993; Barba Navaretti and Venables, 2004; Criscuolo and Martin, 2009; Castellani et al., 2015; Denisia, 2010); (ii) employment creation, especially when MNCs contribute to import substitution and to the expansion of a country's export capacity (Ncunu, 2011; Chaudhuri and Banerjee, 2010 for FDI in agriculture). 
With specific reference to low- and middle-income countries as recipient economies, Vacaflores (2011) studied the relationship between FDIs and employment in 12 Latin American countries and found a positive and significant effect. Latin American countries were among the highest recipients of FDIs starting from the 1980s but, once compared to other regions like South East Asia or Eastern Europe, the impact of FDI was much weaker in terms of employment growth and other parameters of industrial upgrading and competitiveness (Zhang, 2001). In contrast to these fast industrialisers, countries like Mexico did not engage strategically with MNCs, on the contrary their approach was one of "passive open-door policy with limited policy interventions and no industrial policy" (Lall, 1995). As a result, if we look at Mexico as an example, while the development of the auto cluster was impressive - export grew 18\% a year over 1994-2002 - the country grew at a modest 3\% and the expected automotive multiplier did not materialise (Mortimore and Vargara, 2004).

Second, for what concerns indirect effects on host economies, these occur through changes in the capabilities, strategies and performance of local firms, especially their value addition. The standard assumption is that FDIs will determine some kind of technological externalities, contributing to shifts in the local firms' production function, or pecuniary externalities, determining shifts in the local firms' profit function (Blalock and Gertler, 2008; Newman et al., 2014; Santos and Khan, 2018) . Empirical evidence on these impacts is more controversial. Some studies found evidence of technological upgrading at a general level, where local firms learnt from MNCs by observing technologies employed by international actors and attracting employees trained by the same actors (Borensztein et al., 1998; Blomström and Sjöholm, 1999 for a study on Indonesia; Meyer, 2004). While the results based on cross-sector analysis revealed a positive impact of FDIs (see for example Makki and Somwaru, 2004; Aykut and Sayek, 2007), due to the fact that international activities take place in better performing countries, the availability of longitudinal firm level data has led to explore spillovers effects of multinational presence across and within industries, leading to less clear-cut results. In fact, a number of studies have found null or even negative impact of FDIs on the performance of host economies (Gorg and Greenaway 2004).

Moreover, it is important to stress the difference in FDI effects occurring across countries at different stages of development. Although empirical research shows a positive correlation between FDIs and productivity in developed countries (Caves, 1974 on Australia; Globerman, 1979 on 
Canada; Pain and Hubert, 2000 on the United Kingdom), the picture becomes less clear when studies focus on developing countries that do not have sufficiently advanced and well-structured industrial ecosystems (see Andreoni, 2018 for a theoretical discussion and empirical analysis of industrial ecosystems). Xu (2000) carried out a study about more than 40 countries and found positive technology transfer in developed countries but not in developing countries. Similarly, positive effects are found on FDIs in manufacturing firms in the United States but not in Mexico and Venezuela (Atiken et al., 1996). Mixed results are found in a study on Uruguay where there are positive effects of FDIs but only in firms with small technological gaps (Blomstrom and Sjoholm, 1999). Referring to emerging economies, Hanson (2001) claimed that positive effects are very few and Gorg and Greenaway (2004) that most effects would be negative. A broader set of contributions adopting more granular mixed-methods has found that FDIs are not beneficial per $s e$ and that capabilities improvements and learning depend on local firms' absorptive capacity (Kokko 1994), on technological gaps separating foreign and local firms as a source of technological opportunities (Findlay 1978, Blomstrom and Wolff 1997, Castellani and Zanfei 2003), on catching up potential (Meyer and Sinani, 2009), and on the nature of activities involved (Castellani et al. 2015; ).

\subsection{Insights from global value chains and local production systems literatures}

In the last two decades, the impact of FDIs on hosting countries has been increasingly studied through the analytical lenses of global value chains (GVCs). The GVCs literature points at the existence of two critical factors mediating the relationship between FDIs and technology diffusion, i.e., governance and upgrading within and along value chains (Gereffi 1994, 1999 and 2018; Gereffi and Lee, 2016; Ponte et al., 2019; Sturgeon, 2009). First, different types of GVC governance systems determine the ways in which MNCs manage, organize and orchestrate their suppliers on a 'glo-cal' scale and potentially result in 'endogenous asymmetries' (Milberg and Winkler, 2013). Second, upgrading - understood as a positive shift in the competitive position of a firm within and along value chains - depends on several institutional and economic actors in the process of local productive capabilities and linkages development (Gereffi and Lee, 2016; Andreoni, 2019; Dallas et al., 2019). 
Despite the importance that this approach gives to understanding the interrelations at a global level, the sectoral characteristics are still important for many reasons. The ability of countries to link up through backward linkages, and then either add value forward or remain upstream, is strongly related to the specific sectors and types of FDIs a country is able to attract and the types of linkages that develop from and around the FDIs (Andreoni, 2019). Value creation and spaces for learning and development are distributed unevenly across value chains in different sectors (Andreoni and Chang, 2017), most often involving a fine-slicing of production and R\&D activities also within sectors (Mudambi 2009, Papanastassiou et al. 2019).

The Local Production System (LPS) framework (Andreoni, 2019) points to the importance of looking at different types of linkages in a developing country's production system, how they develop both vertically along the FDI-driven global value chain and horizontally in the local economy at the intersection of several sectoral value chains and other actors (including public ones such as industrial research intermediate institutions and services providers). The local production system is made of multiple types of production, technological, consumption and fiscal linkages which are based on the existence of specific set of capabilities. This framework points to the importance of focusing on the productive, technological and organisational capabilities of local firms, linkages development across industries, institutions and political economy factors (Hirschman, 1958; Amsden, 1989; Chang, 1994; Lall, 2000; Andreoni, 2019; Andreoni and Chang, 2019) as well as the nature of investment projects and the technological level of investors (Castellani and Zanfei 2003, 2006).

Considering the multiple factors suggested within the GVCs and LPS, we can conclude that technology spillovers may not accrue when host economies have a weak industrial base therefore, FDIs might trigger low or no technological upgrading effects (in our specific case, robotisation) when occurring in local environments that are not responsive to the stimuli of foreign capital injections. In this sense, capability creation, absorptive capacity and production linkages are a key concern when considering spillovers to the rest of the economy (Jindra et al., 2009; Zanfei and Saliola, 2009; Meyer and Sinani, 2009) and different types of value chain integration (Ponte and Gereffi, 2019; Andreoni, 2019). 


\section{Industry context: how fragmentation of production and concentration of power shaped the automotive sector}

When studying the relationship between FDIs and robotisation, a focus on the automotive sector is particularly relevant due to three specific structural characteristics of this industry. That is, its GVC structure and concentration, its early adoption of robots and the geographical distribution of its activities.

First, the fragmentation of production and the huge amount of FDIs resulting from both outsourcing and concentration trends, deeply reshaped the industry and contributed to the 'producer-driven' definition of the automotive GVC (Gereffi, 1994). The automotive GVC is characterised by a small set of final assemblers with relatively high market power, an increasingly exclusive club of Tier 1 suppliers, which are also becoming closer to the final OEMs (Wong, 2017), and a series of Tier 2 and Tier 3 suppliers which are more dispersed despite being increasingly controlled by OEMs. The last decades have witnessed a consolidation in the automaker markets around sixteen major players. In 2015, ten OEMs accounted for three quarters of global production with the top five accounting for $50 \%$ of total production (International Organization of Motor Vehicle Manufacturers, 2015) ${ }^{2}$. Global firm leaders focus on the design part of vehicles that is where an important share of the value added lies (Sjoestedt, 1987). Preproduction and engineers activities, "where conceptual designs are translated into the parts and sub-systems that can be assembled into a drivable vehicle, remain centralized in or near the design clusters that have arisen near the headquarters of lead firms" (Sturgeon et al., 2008: 8).

This concentration phenomenon has been accompanied by the rise of first tier mega suppliers. Over the past four decades component manufacturers dropped from 40.000 in 1970 to less than 3000 in 2015 (Wong, 2017). Hence, fewer larger first-tier suppliers have survived and consolidated while, at the same time, they have developed close relationship with big OEMs. In this emerging configuration of the automotive value chain, OEMs still control and manage the entire supply chain. However, since OEMs are the mere final assembler of the product à la Foxconn (McGee, 2016), they put pressure on their suppliers, especially Tier 1, and have forced them to take

\footnotetext{
${ }^{2}$ The forecast of production engineered by the leading OEM (less than 10) is $83 \%$ of global output in light vehicles (IHS Markit,
} 2018) 
increasing responsibilities in investments and supply chain management. Indeed, given the small number of global automotive firms and their strong purchasing power, suppliers can be forced towards the adoption of specific standards, information systems and even production technologies. As pointed out by Sturgeon et al. (2009), "with consolidation, we must question the staying power of smaller, lower tier, local suppliers" and, thus, the increasing "endogenous asymmetries" along the value chain in different countries (Milberg and Winkler, 2013). Indeed, the relationship between OEMs and suppliers appear to follow similar global benchmarks, but can also develop differently in different country contexts.

Second, the automotive sector absorbs almost $37 \%$ of the total number of industrial robots worldwide (IFR, 2015), a share which makes it the top sector for adoption of robots. Automotive has benefitted from a continuous technology push, stemming from investment in automated production technologies from major car producers since the 1970s. The automotive sector has always been the bedrock of manufacturing automation advances due to its high-volume production, standardisation and production and product modularisation. This characterisation stems from the degree of transnational dispersion of production in automotive industry (Birkinshaw J. et al., 2016; Winroth and Bennett, 2017; Serfati and Sauviat, 2019). Moreover, the automotive sector provides an effective illustration of the possibility that companies can create and well manage long-distance business relationships (Sturgeon and Lee, 2005).

Third, the automotive sector is characterised by sectoral and market dynamics resulting in a specific spatial organisation and distribution of production. The fragmentation of automotive production is based on networks that tend to organise regionally, much more than globally (Jetin, 2018). Regionalisation was favoured by the widespread adoption of modularisation in the 1990s (Sako, 2003) and by the importance to be 'next-door' to car assemblers, especially for Tier 1 suppliers that are located close to (when not fully integrated with) assembly plants, in order to better synchronise just-in-time-delivery of complex modular units (Frigant and Lung, 2002).

MNEs are key actors affecting the characteristics of automotive industry which we have highlighted; they contribute to industrial concentration, as well as to technology diffusion and to the geographic dispersion of production. The role played by FDIs in robot adoption in particular 
makes a special case that needs to be explored from this perspective. Sections 4 and 5 will provide some evidence in this sense.

\section{Data}

This study builds on the use of two innovative sources of data that have not been matched before, to the best of our knowledge. The paper undertakes a quantitative approach, based on the analysis of secondary data that have been collected by international organisations, namely the fDi Intelligence of the Financial Times for the fDi market dataset and the International Federation of Robotics for data on industrial robots. FDIs data and industrial robot data are combined through some descriptive statistics so to explore correlations between industrial robot adoption and FDIs. We added a further element to this, as we unpack the automotive sector into two main sub segments of its value chain, e.g. automotive assembly and automotive components, and we observe the relationship between FDIs and industrial robots along these two segments for 2005-2014.

International Federation of Robotics dataset collects data on the diffusion of industrial robots, produced by nearly all industrial robots suppliers world-wide (IFR, 2015). According to International Organisation for Standardization, an industrial robot is defined as: "an automatically controlled, reprogrammable, multi-purpose manipulator programmable in three or more axes, which may be either fixed in place or mobile for use in industrial automation applications" (IFR, $2015)^{3}$. Based on this definition, the IFR dataset provides data on the number of robots by industry following ISIC rev. 4 classification, by country and per year. Moreover, for the automotive sector IFR dataset provides also a sub-classification of different segments of the value chain. Data on stock of robots are expressed in number of units adopted.

fDi Markets database is an online dataset that compiles data on cross-border investment projects with details on the sectors and sub sectors, whose classification corresponds to NACE Rev.2 or NAICS 07, on industry activities (i.e. the business functions involved in the FDI project, including inter alia: Manufacturing, R\&D, Design Development and Testing, HeadQuarter services, Sales and Logistics) and on locations of investments with different degrees of geographical aggregation. Out of more than 142,000 observations of investments to which we have access over the 2003-

\footnotetext{
${ }^{3}$ https://www.iso.org/obp/ui/\#iso:std:iso: 8373:ed-2:v1:en
} 
2014 period, we use investments in the automotive industry, considering the two industry sectors Automotive OEM and Automotive Components. Among the numerous valuable pieces of information that fDi Markets provides, we use destination_country, year, industry_activity and sub_sector. Out of all industry activities detected for automotive industry and for its sub-sectors we considered just Manufacturing activities (hence excluding sales, R\&D and headquarter services, etc.), in order to provide full consistency with the other data coming from IFR which are just related to manufacturing applications of industrial robots. In addition, to match our two sources of data we use a conversion table supplied by the US Bureau of Census ${ }^{4}$.

We refer to 34 countries, which constitute almost $97 \%$ the robots' adoptions and $99 \%$ of the inward FDIs in the automotive sector. Tables 1 and 2 use data from our main sources to highlight the geographic concentration of industrial robot adoption and of FDIs in the automotive industry: the top 5 countries account for almost $60 \%$ of inward FDIs in this sector, while the top 5 adopting countries account for about $80 \%$ of all robots in the world.

[Tables 1 and 2]

The automotive segments we consider for our analysis are: ISIC 2910 motor vehicle manufacturing (OEM assembly), 2931 metal and plastic parts, 2933 electric/electronic parts and 2939 other parts, which includes car seats, airbags and safety belts. As aforementioned, we analyse the relationship between FDIs and industrial robots across 34 countries for two periods: i) a ten-year period (20052014) with a data disaggregation distinguishing two segments of the industry - i.e. Automotive OEM and Automotive Components; ii) five-year period (2010-2014) considering four segments of the automotive value chain - i.e. 2910 (motor vehicle assembling), 2931 (metal parts and plastics), 2933 (electric and electronic parts), 2939 (other parts which include seats, airbags, safety belts). Section 5 will present our two parts of the analysis.

Although the two datasets present extremely rich and detailed information, they do have some limitations. First, within the automotive classification there are two unspecified classes, which are Unspecified AutoParts (class 2999) and Automotive Unspecified (class 299). We inserted sub-

\footnotetext{
${ }^{4}$ http://www.census.gov/eos/www/naics/concordances/concordances.html) from NAICS to ISIC rev. 4.
} 
class 2999 within the auto component sub-class and redistributed 299 proportionally between Auto Assembly and Auto Parts. Instead, for the bubble graphs at four sectors disaggregation below we could not insert any of these classes ${ }^{5}$. The second limitation is due to the fact that up until 2010 IFR data referring to the United States, Mexico and Canada were aggregated. Figures for Canada and Mexico started "from zero" in 2010 when they were disaggregated.

\section{Stylised facts on the relationships between FDIs and robotisation}

The analytical investigation of the relationship between FDIs and robotisation is structured in two main steps - comparative and dynamic - and, for each of them, we identify patterns at different levels of disaggregation of the automotive industry. By doing so we aim at capturing first the heterogeneous rate of robotisation across different countries and segments of the automotive value chain; and second how they have followed different patterns over the last two decades.

\subsection{Comparative analysis}

We conducted our first comparative analysis at two levels of disaggregation and used descriptive statistics to show the relationship between FDIs inflow and industrial robots adoption within the two segments 2910 (Automotive OEMs) and 2930 (Automotive Components). Figure 1 and 2 present the distribution between industrial robots in these two segments and inward FDIs. Our aim is to show how different countries are placed differently according to the automotive segments each graph refers to. While it is not surprising to find the biggest automotive players in the top right quadrant, with these graphs we aim to emphasise the different position of developed, emerging and developing countries between the Assembly and the Components segments.

Figure 1 illustrates the distribution of FDIs at the OEMs level; we use the sum of inward FDIs between 2005 and 2014 and the stock of industrial robots in the same time frame. Although the lack of strong correlation is an interesting finding per se, as it points to high heterogeneity even for the assembly segment of the automotive sector, interesting patterns emerge once these scatterplots are divided into quadrants.

\footnotetext{
${ }^{5}$ We contacted the administrators of IFR dataset in Germany and after a careful analysis we claimed that these data could not be inserted in any other classes.
} 
[Figure 1]

At the top of Figure 1, there are either industrialised countries or fast industrialisers: the upper left quadrant includes developed economies, which have a strong presence of industrial robots in their automotive industry but do not attract a high number of FDIs (e.g., Japan, South Korea, Germany, Italy). Interestingly these are all countries that undertook important transformation plans to shift their entire economy towards automated production. If we look just at the automotive sector, this occurred despite a relative lower number of FDIs if compared to developed countries on the top right quadrant. Instead, in the upper right quadrant one finds countries where the increasing number of FDIs seems to be correlated more with the increase in robots adoption. These are countries that either have a long tradition in the sector and still play a pivotal role attracting FDIs (e.g. United Kingdom and Spain) or they are big attractors of FDIs and rapidly industrialising countries (e.g. China, Mexico within North America, and to some extent Brazil). In the bottom part of the graph there are both developed countries with a modest automotive sector and emerging economies, such as the Eastern European countries, linked up to the German automotive value chain. Dynamic economies such as Thailand, Turkey, Russia and India are also present in the right part of the graph, thus showing both a relatively high degree of attractiveness for FDIs and a general upgrade of the OEMs-related production processes (especially Turkey); these are countries growing a lot as a result of policies that encourage the development of the automotive sector as well as opening doors to FDIs (Barnes and Black, 2017).

Automotive components graph distribution across countries is presented in Figure 2. Within the top quadrants (i.e., with a large number of robots), as expected, we find industrialised countries with a highly developed automotive sector. Among emerging economies in the upper quadrants, the only case (apart from China) is Thailand, which is catching up quickly, also as a result of a new and dynamic automotive sector (Deloitte, 2019). This example could indicate that Thailand was not only able to attract an important number of FDIs, but it has also been able to channel them in the direction of technological diffusion and upgrade via development of supply chains of components producers (Sadoi, 2012). Other countries, such as India, Brazil and Russia received more FDIs than Thailand, but their respective auto components segments use fewer industrial robots (IFR, 2015). A final consideration on these first graphs is that the better position that Thai 
components' segment has vis a vis its OEMs one (previous graph) is an element that suggests the presence of an important system of local suppliers. Differently, taking as an example the sluggish position of South Africa's auto components, it confirms the low number of suppliers' activities both in terms of international activities (FDIs) and in terms of local technological pull (Black A. et al., 2017).

[Figure 2]

\subsection{Dynamic analysis}

The second part of our analysis presents a series of bubble graphs that intend to show the trend of FDIs and industrial robot adoption across different segments of the automotive value chain at a finer level of disaggregation and over time. We use this tool as it allows us to plot on the same graph our two variables of FDIs and industrial robots against a time dimension on the horizontal axis. The analysis takes advantage of the high disaggregation of our data that is possible for the 2010-14 period, thereby allowing us to consider the following four industry segments: 2910 (motor vehicle assembling), 2931 (metal parts and plastics), 2933 (electric and electronic parts), 2939 (other parts which include seats, airbags, safety belts). When we indicate 2930 we refer to the sum of all components parts $(2931,2933,2939)$. In order to build these graphs, we considered the 20 countries (from Table 2) that received the largest amounts of FDIs in the automotive sector in the period 2010-2014. The bubble graphs presented in Figure 3 and 4 correlate three variables, using the value of FDIs inflow (vertical axis), the number of robots (the size of the bubble), and how this relation changes over a four-years' time horizon (horizontal axis). Figure 3 depicts an interesting dynamic relation between FDIs and industrial robots across time and across different segments of the value chain.

First, vehicle assembly segment (2910) is characterised by a stable and massive use of robots (the size of the bubble) and a decreasing level of FDIs (except in the final year), the latter presumably as a consequence of the global financial crisis and the impact on global demand of automotive and of cars in particular (Van Biesebroeck and Sturgeon, 2010). However, the global crisis affected countries differently. While hitting severely American and, to a less extent, European companies supported by intense cross border activities, the crisis gave at the same time the opportunity to 
Indian and Chinese auto manufacturers to expand their markets and to become world players (UNIDO, 2009; Bai, 2012). In this sense, FDIs dynamics are also very much related to global and especially developed world's demand cycles. The increase of FDIs in 2014 went in parallel with the first increase in car registration in the European market after six years of recession (Rosemain, 2014).

Second, auto components sectors (2931, 2933 and 2939) appear to follow a different pattern, which is less related to major shocks at the global level; in fact, in 2012, one the most problematic years for motor assemblers, sees a peack in both FDIs and in industrial robots' adoption for component manufacturers. This could suggest that FDIs in assembling (OEMs) and in components segments of the value chain operate differently. While FDIs in all automotive segments fluctuate significantly, and particularly so in the assembly stage, the adoption of industrial robots is slow but pretty stable, showing that this production technology is steadily becoming more diffused in the industry, with a remarkable increase in the case of components. Therefore, the adoption of robots and the presence of inward FDIs are not clearly correlated over time, although some evidence exists that the relation is negative in the case of assembly and slightly positive in the case of components at least in the first part of the examined period. We replicated the same exercise in Figure 4 with a two level disaggregation so to better highlight how assembly and components segments behave differently.

[Figure 3]

[Figure 4]

Figure 5 zooms into Figure 3 with a focus only on the auto components segment. A closer look at different sub-segments of auto components reveals further heterogeneity within this segment, and this may have to do with the specific characteristics of production processes and technologies required for different auto components. Examining in detail the reasons underlying these differences is beyond the scope of this paper $^{6}$. Suffice here to observe diverging patterns of FDI

6

Although there are a number of reasons underlying this heterogeneity in robots adoption across different components, one of the main ones is related to the degrees of freedom that companies have in automating (or not) their production processes for specific components. For instance, an important number of metal parts' operations have to be produced automatically due to quality and safety reasons, no matter where they are produced. Some specific spot welding and laser welding operations are characterised by 
and robot adoption: Metal parts (2931, the green bubbles in Figure 5) show a peak of FDIs in 2012 and a steady substantial increase in industrial robots; airbag, safety belts and seats (2939, yellow bubbles) present a pretty stable, slightly decreasing, level of FDIs investments with a stable increase in the use of industrial robots. Electrical and electronic parts (2933, the blue bubbles) are attracting an important number of FDIs but they still present a small, although increasing, number of industrial robots.

[Figure 5]

Interestingly, the more we focus on countries at the technological frontier the more robots tend to be used across more segments of the automotive value chain, including some of those which are traditionally more labour-intensive. For instance, looking at NAFTA and Germany (Figure 6), even production of electric/electronic parts (grey bubble) and leather/synthetic seats and airbags (yellow bubble) appear to be associated with the adoption of an important number of robots. For illustrative purposes we focus on a selection of countries which have different degrees of involvement in the global automotive value chain ${ }^{7}$, and we observed that there is no strong correlation between the number of robots adopted and the inflow of FDIs. This is visualized in Figure 6 as there is presence of big sized bubbles even in relation to a relatively small amount of inward FDIs (e.g., see Germany).

[Figure 6]

\section{Discussion}

The automotive sector is characterised by specific dynamics that influence the distribution of its international activities. More than truly global, over the last decades the sector has increasingly clustered in specific regional areas, the most important of which are NAFTA, Germany and Eastern Europe, East Asia, Argentina/Brazil to a certain extent and, more recently, China.

operational tasks that, for the quality and ergonomics of the process, can be only automated. Differently, the production of seats or airbags are mainly constituted by operations that could be automated (and they are likely to be increasingly automated) but can still be performed manually.

\footnotetext{
${ }^{7}$ For all of these countries unclassified robots represent less than $5 \%$ of all adopted robots over the period we considered.
} 
Historically, the automotive sector has been a major driver of industrialisation in several successful country experiences. The length and complexity of its value chain, alongside the development of production and technological complementarities, allowed countries involved in the automotive sector to achieve several goals.

The automotive sector has also been a fertile field for many improvements in production technologies, being the sector characterised by intensive economies of scale and by the use of automated machines since the 1970s (Sjoestedt, 1978). Industrial robots were not an exception in this respect, and the first introduction of spot welding and arc welding robots took place in the automotive sector (APO, 1987). The use of industrial robots, despite not being recent, experienced a growth due to improvements in technologies, the consequent increase in productivity and, to a certain extent, flexibility.

Our descriptive statistics suggest that it is difficult to claim strong correlation between inward FDIs and industrial robots' adoption in the automotive sector, especially when we look for patterns across different segments of the value chain - assembling and components production - and for different types of components. However, there exist some interesting FDI related patterns that characterise the adoption of new technologies. That is, the heterogeneity of FDIs-led robotisation especially when comparing the Automotive OEM with Automotive Components. Building on the literature, existing evidence and our new descriptive analyses, we formulate the following three sets of considerations and hypotheses for further research.

First, Automotive OEMs clearly are the main drivers of robotization; if we look at the number of robots (e.g. the size of the bubbles), OEMs encompass the majority of industrial robots (IFR, 2015). This is largely expected because OEMs are large in size, have a high market power and have the capacity to invest in new technologies and because of the operations they perform. The assembly of a motor vehicle requires an increasing number of robots in the pressing shop, the body shop and the paint shop. Thus, we glimpse two main dynamics that develop as effect of FDIs from big OEMs. On the one hand, they are the first adopters of industrial robots in their new facilities, and this is increasingly the case with the increase in quality standards and safety issues that led to the introduction of, for instance, electrostatic coating in the paint shop and different types of new 
laser and spot welding robotic cells in the press shop and body shop. On the other hand, they could also activate foreign capital inflows involving components suppliers, especially big international Tier 1 suppliers which are closely linked to OEM operations. In this sense, since OEMs are the leading actor for organisational and technological innovation, they also have the power and ability to manage the modular production and the mastering of new technologies both at the plant level and along the supply chain (Jacobides et al., 2015).

Second, FDIs-induced robotisation driven by OEMs is however not sufficient to fully explain our data when we look at robotisation in the components' segments of the automotive value chain. It appears that FDIs per se are not a crucial driver for this segment of the value chain. First, as shown in our bubble graphs, there is no correspondence between the amount of FDIs and the increase in robots' adoption (the size of our bubbles, see Figure 5) over time. Instead, it seems that the diffusion of industrial robots is a steady, although slow, trend that continued to increase despite the decrease both in inward auto components FDIs and the use of industrial robots at the OEMs level. While significant differences emerge across segments of the automotive industry, these unclear correlations between FDIs and robotisation over time might reflect a remarkable heterogeneity of FDI induced adoption patterns also across countries.

Third, the most successful countries in terms of industrial robot adoption in the components segment, such as Thailand, Czech Republic and Turkey, have adopted consistent policy packages at the national level in order to attract FDIs while boosting complementary aspects (e.g. education, infrastructure, R\&D incentives) for technology upgrade (see Barnes et al., 2017 for Thailand; Taymaz and Yilmaz, 2017 for Turkey (although they state that the success is mitigated by the lack of organizational capabilities); Hill, 2007 for Czech Republic). In other words, these countries made a general effort to improve their position in global value chains including both FDI attraction and a conscious effort to upgrade their local production system towards the development of an ecosystem of domestic suppliers. An industrial ecosystem is based on the development of a series of complementarities based on the existence of linkages between close but dissimilar types of firms. Firms and organisation that are linked to each other along sectoral value chains (vertical linkages), and across different sectors (horizontal linkages) trigger the development of complementary capabilities (Andreoni, 2019). Thailand is one example in this sense. It is the 
developing country (China excluded) with the highest number of industrial robots, and one of the highest in the automotive sector (IFR, 2015). The 'robotisation' of the country is based on a series of policies that aim at building up the local ecosystem. Demand and supply policies have been combined in a way where technological skills push met demand pull in a country where firms have been 'accompanied' by fiscal incentives to adopt industrial robots. Lastly, a wide range of enabling institutions and infrastructures permitted the Thai government to provide the right set up for firms both local and international (Barnes et al., 2016). Because components production suppliers are more fragmented than big OEM assemblers, they rely on a series of close complementarities that can be fully developed and explored in geographical proximity with OEMs and with the right incentives provided from government, MNCs and other local intermediate actors. This third set of consideration restates the importance of strategic engagements with FDIs in the host economy, including restricting the scope and modalities of operation of MNCs, especially with respect to their engagement with domestic suppliers. High technologies require time to be absorbed and mastered and they build up on production systems that are complex and need to be adapted to local conditions. And this is why to strengthen the relationship between FDI and robotisation, FDIs should be strategically managed through appropriate industrial policy.

\section{Conclusion}

This paper examines the relationship between inward FDIs and industrial robots' adoption, disaggregating the automotive sector and looking at how FDIs and industrial robots are distributed across different segments of the value chain. The granularity of our data permits to innovatively combine two crucial information for the automotive sector: inward FDIs and process technology upgrade. This is a first, largely descriptive attempt to explore the relation between FDIs and robots' adoption, as a manifestation of how FDIs could act as a trigger for a technological upgrade. We found that different segments of the value chain as well as different groups of countries are characterised by distinct patterns of FDIs and robot adoption. While FDIs play a role for the adoption of robots in the OEMs segment (particularly of emerging countries), it seems less the case for the components segment. We put forward some potential explanations for this, specifically focussing on the role that structural characteristics of the industry and policy play in shaping the trajectory of industrial robots' adoption. 
Our study has important limitations. First, we cannot claim any causality. This is an exploratory study that only aims to shed some lights on heterogenous dynamics of robotisation. We pointed to correlations that exist in some cases and do not show up in others, and puts forth some conjectures on the possible determinants of such correlations (and absence thereof). Second, the existence of unspecified classes is particularly limiting in the disaggregation at four segments. Nonetheless, our results open for a new stream of research that goes beyond the existent empirical literature on the new technologies, which remains at the macro level and mainly focusses on the impact of robotics on labour. We have highlighted the importance of studies at a fine-grained sectoral level, which might help disclose hidden dynamics and yield interesting insights that are difficult to grasp at an aggregated level.

\section{References}

Amsden, A. (1989) Asia's Next Giant: South Korea and Late Industrialization, NY: Oxford University Press

Amsden, A. (2001) The Rise of The Rest: Challenges to the West From Late-Industrializing Economies, Oxford: Oxford University Press

Andreoni, A. (2019) 'A Generalised Linkage Approach to Local Production Systems Development in the Era of Global Value Chains, with special reference to Africa', in Kanbur R., Noman A. and Stiglit, J., Quality of Growth in Africa, New York: Columbia University Press

Andreoni, A. (2018) 'The Architecture and Dynamics of Industrial Ecosystems: Diversification and Innovative Industrial Renewal in Emilia Romagna', Cambridge Journal of Economics, Vol. 42, pp. 1613-1642

Andreoni, A. (2014) 'Structural learning: Embedding discoveries and the dynamics of production', Structural Change and Economic Dynamics, Vol. 29, pp. 58-74

Andreoni, A., Chang H-J. (2019) 'The Political Economy of Industrial Policy: Structural Interdependencies, Policy Alignment and Conflict Management', Structural Change and Economic Dynamics

Andreoni, A., Chang, H.J. (2017) 'Bringing production and employment back into development' Cambridge Journal of Regions, Economy and Society, Vol. 10, pp. 173-187

APO, (1987) Applications of Industrial Robots. Selected Experiences, Tokyo: Asean Productivity Organisation 
Atiken, B., Harrison, A., Lipsey, R. (1996) 'Wages and foreign ownership. A comparative study of Mexico, Venezuela, and the United States', Journal of International Economics, Vol. 40, pp. $345-371$

Aykut D., Sayek S. (2007), "The Role of the Sectoral Composition of Foreign Direct Investment on Growth", in Piscitello L. and Santangelo G. Do Multinationals Feed Local Development and Growth?, Amsterdam: Elsevier

Bai, Xue (2009) 'The Effects of the 2007-2009 Economic Crisis on Global Automobile Industry', Applied Economics Theses. Paper 2.

Baldwin, R. (2016) 'The Great Convergence. Information Technology and the New Globalization', Boston: Belknap Press

Barba Navaretti, G., Venables, A. (2004) Multinational firms in the world economy, Princeton University Press

Barnes, J., Black, A. (2017) 'Developing a South African automotive Masterplan to 2035 in the context of Global Value Chain drivers: Lessons for second tier automotive economies', Paper prepared for the GERPISA Colloquium.

Barnes, J., Black, A., Techakanont, K. (2016) 'Industrial Policy, Multinational Strategy and Domestic Capability: A comparative analysis of the development of South Africa's and Thailand's Automotive Industries', European Journal of Development Research, Vol. 29, pp. 3753

Birkinshaw J., Zimmermann A., Raisch S. (2016), "How Do Firms Adapt to Discontinuous Change? Bridging the Dynamic Capabilities and Ambidexterity Perspectives", California Management Review, Vol. 58, pp. 36-58

Black A., Makundi B., McLennan T. (2017), “Africa’s Automotive Industry: Potential and Challenges", Working Paper Series n. 282, African Development Bank, available at: https://www.afdb.org/fileadmin/uploads/afdb/Documents/Publications/WPS_No_282_Africa\%E 2\%80\%99s_Automotive_Industry_Potential_and_Challenges.pdf

Blalock G., Gertler P. (2008), "Welfare gains from Foreign Direct Investment through technology transfer to local suppliers", Journal of International Economics, Vol. 74, pp. 402-421

Blomström, M., Sjöholm, F., (1999), 'Technology transfer and spillovers: does local participation with multinationals matter?', European Economic Review, Vol. 43, pp. 915-923

Blomstrom, M., Wolff, E. (1997) 'Growth in a dual economy', World Development, Vol. 25, pp. 1627-1637 
Borensztein, E., J. De Gregorio, and J-W, Lee. (1998) 'How Does Foreign Direct Investment Affect Economic Growth?', Journal of International Economics, Vol. 45, pp. 115-135.

Castellani, D., Mancusi, M.L., Santangelo, G., Zanfei, A. (2015) 'Exploring the links between offshoring and innovation', Economia e Politica Industriale, Vol. 42, pp. 1-7

Castellani, D., Zanfei, A. (2003) 'Technology gaps, absorptive capacity and the impact of inward investments on productivity of European firms', Economics of Innovation and New Technology, Vol. 12, pp. 555-576

Castellani, D., Zanfei, A. (2006) Multinational firms, innovation and productivity, Cheltenham: Edward Elgar.

Cantwell, J. (1989) Technological Innovation and Multinational Corporations, Basil Blackwell Cambridge, MA.

Caves, R.E. (1974) 'Multinational Firms, Competition and Productivity in Host-Country Markets', Economica, Vol. 42, pp. 176-193

Chang, H-J (1994), The Political Economy of Industrial Policy, Basingstoke: Macmillan.

Chang, H.-J. (2004), "Regulation of Foreign Investment in Historic Perspective", The European Journal of Development Research, Vol. 16, pp. 687-715

Chang, H.-J. and Andreoni, A. (2020), "Industrial Policy in a Changing World: Neglected Issues and New Challenges', Development and Change, forthcoming.

Chaudhuri, S., Banerjee, D. (2010), "FDI in agricultural land, welfare, and unemployment in a developing economy", Research in Economics, Vol. 64, pp. 229-239

Cimoli, M., Dosi, G., Stiglitz J. (2009) 'Industrial Policy and Development: The Political Economy of Capabilities Accumulation', Oxford: Oxford University Press

Criscuolo, C., Martin, R. (2009) 'Multinationals and US productivity leadership: Evidence from Great Britain', The Review of Economics and Statistics, Vol. 91, pp. 263-281.

Dallas, M. Ponte, S. Sturgeon, T. (2019) 'Power in global value chains', Review of International Political Economy, Vol. 26, pp. 666-694

Deloitte (2019), "Economic Outlook Report 2019", Deloitte Thailand, available at: https://www2.deloitte.com/content/dam/Deloitte/th/Documents/about-deloitte/th-about-thailandeconomic-outlook-2019.pdf

Denisia, V. (2010) 'Foreign Direct Investment Theories: An Overview of the Main FDI Theories', European Journal of Interdisciplinary Studies, Vol. 2, pp. 104-116 
Dunning, J. (1993), Multinational enterprises and the global economy, Boston: Addison-Wesley Publishing Company

Feenstra, R.C, Hanson G.H. (1995) 'Foreign Direct Investment and Relative Wages: Evidence from Mexico’s Maquiladoras’, NBER working paper 5122

Findlay, R. (1978) 'Relative backwardness, direct foreign investment, and the transfer of technology: A simple dynamic model', Quarterly Journal of Economics, Vol. 92, pp. 1-16.

Frigant, V. and Lung, Y. (2002) 'Geographical proximity and supplying relationships in modular production', International Journal of Urban and Regional Research, Vol. 26, pp.742-755

Gereffi G. (2018), “Global Value Chains and Development: Redefining the Contours of 21st Century Capitalism”, Cambridge: Cambridge University Press.

Gereffi, G. (1994) 'The organization of buyer-driven global commodity chains: How U.S. retailers shape overseas production networks', pp. 95-122 in: Gereffi G. and Korzeniewicz M., Commodity Chains and Global Capitalism, Westport, CT, Praeger.

Gereffi, G., Lee, J. (2016) 'Economic and Social Upgrading in Global Value Chains and Industrial Clusters: Why Governance Matters', Journal of Business Ethics, Vol. 133, pp. 25-38

Globerman, S. (1979) 'Foreign Direct Investment and "Spillover" Efficiency Benefits in Canadian Manufacturing Industries', Canadian Journal of Economics, Vol. 12, pp. 42-56.

Görg H., Greenaway D. (2004) 'Much Ado about Nothing? Do Domestic Firms Really Benefit from Foreign Direct Investment?', World Bank Research Observer, vol. 19(2), pp. 171-197

Hirschman A.O. (1958), The Strategy of Economic Development, Yale University: New Haven.

International Federation of Robotics (2015) 'The Impact of Robots on Productivity, Employment and Jobs', Positioning paper

Jacobides M., MacDuffie J. Tae J. (2015), "Agency, structure, and the dominance of OEMs: Change and stability in the automotive sector", Strategic Management Journal, Vol. 37, pp. 19421967

Jetin, B. (2018) 'Production network of the Asian automobile industry: regional or global?', International Journal Automotive technology and Management, Vol. 18

Jindra, B., Giroud, A., Scott-Kennel, J. (2009) 'Subsidiary roles, vertical linkages and economic development: Lessons from transition economies', Journal of World Business, Vol. 44, pp. 167179

Kokko, A. (1994) 'Technology, market characteristics, and spillovers', Journal of Development Economics, Vol. 43, pp. 279-293 
Lall, S. (2000) 'FDI and Development: Policy and Research Issues in the Emerging Context', $Q E H$ Working Paper Series

Lall, S. (1995) 'Industrial strategy and policies on foreign direct investment in East Asia', Transnational Corporations, Vol. 4, pp. 1-26

Lall, S. (1979) 'The international allocation of research activity by U.S. multinationals', Oxford Bulletin of Economica and Statistics, Vol. 41, pp. 313-31

Lee, K. (2016) Economic Catch-Up and Technological Leapfrogging. The Patch to Development and Macroeconomic Stability in Korea, United Kingdom: Edward Elgar Publishing

Lung, Y. Van Tulder, R. Carillo, J. (2004) Cars, Carriers of Regionalism? New York: Palgrave Macmillan.

Makki S., Somwaru A. (2004), "Impact of Foreign Direct Investment and Trade on Economic Growth: Evidence from Developing Countries", American Journal of Agricultural Economics, Vol. 86, pp. 795-801

McGee, P. (2016) 'Germany's carmakers gear up for tech challenge', available at: www.ft.com/cms/s/0/27d9ead0-dfd1-11e5-b072-006d8d362ba3

Meyer, K., Sinani, E. (2009) 'When and where does foreign direct investment generate positive spillovers? A meta-analysis', Journal of International Business Studies, Vol. 40, pp. 1075-1094

Milberg, W., Winkler, D. (2013) Outsourcing Economics, Cambridge: Cambridge University Press

Moeti, K.B., (2005) 'Rationalization of government structures concerned with foreign direct investment policy in South Africa', unpublished doctoral thesis, Faculty of Economic and Management Sciences, University of Pretoria, Pretoria

Mortimore, M. Vergara, S. (2004) 'Targeting Winners: Can Foreign Direct Investment Policy Help Developing Countries Industrialise?', The European Journal of Development Research, Vol. 16, pp. 499-530

Mpanju, A.K., (2012) 'The impact of foreign direct investment on employment creation in Tanzania', International Journal of Business Economics \& Management Research, Vol. 2, pp. $126-139$

Mudambi, R. (2008) 'Location, control and innovation in knowledge-intensive industries', Journal of Economic Geography, Vol. 8, pp. 699-725

Ncunu, A.E. (2011) 'The dynamics of foreign direct investments in central and Eastern Europe under the impact of international crisis of 2007', CES Working Papers 3-1, pp. 81-91 
Newman C., Rand J., Talbot T., Tarp (2014), "Technology transfers, foreign investment and productivity spillovers: evidence from Vietnam", IIS Discussion Paper, available at: https://www.tcd.ie/triss/assets/PDFs/iiis/iiisdp440.pdf

OECD (2017) The Next Production Revolution: Implications for Governments and Business OECD Publishing: Paris.

Saliola, F., Zanfei, A. (2009) 'Multinational firms, global value chains and the organisation of knowledge transfer', Research Policy 38(2009) 369-381

Pain, N., Hubert, F. (2000), 'Inward Investment and Technical Progress in the United Kingdom Manufacturing Sector', NIESR Discussion Paper 175.

Papanastassiou, M., Pearce, R., Zanfei, A. (2019) 'Changing Perspectives on the Internationalization of $\mathrm{R} \& \mathrm{D}$ and Innovation by Multinational Enterprises. A Review of the literature', Journal of International Business Studies

Ponte S., Gereffi, G. and Raj-Rechert G. (2019), "Handbook of Global Value Chains" Cheltenham, UK and Northampton, USA: Edward Elgar.

Rosemain, M. (2014) 'European Car Sales Jump 7.6\% as Price cuts help Renault', Bloomberg article, available at: https://www.bloomberg.com/news/articles/2014-03-18/european-car-salesjump-7-6-as-price-cuts-help-renault

Sadoi Y. (2012), "Technological capability of automobile parts suppliers in Thailand", in Rasiah R., Lin Y., Sadoi Y. Innovation and Industrialization in Asia, London: Reutledge

Santos E., Khan S. (2018), "Determinant Factors of Pecuniary Externalities”, The International Journal of Business and Management, Vol. 6, pp.180-198

Safarian, A.E. (1999) 'Host country policies towards inward foreign investment in the 1950s and 1990s', Transnational Corporations

Sako, M. (2004) 'Supplier development at Honda, Nissan and Toyota: comparative case studies of organizational capability enhancement', Industrial and Corporate Change, Vol. 13, pp. 281308

Saliola, F., Zanfei, A. (2009) "Multinational firms, global value chains and the organisation of knowledge transfer" Research Policy 38(2009) 369-381

Serfati C., Sauviat C. (2019), "Global Supply Chains and intangible assets in the automotive and aeronautical industries", Research Department Working Paper No. 43, International Labour Office (ILO) 
Sjoestedt L. (1987), “The Role of Technology in Automobile Design and Production", IIACA (International Institute for Applied Systems Analysis", Working Paper 87-029

Sturgeon, T. (2009) 'From commodity chains to value chains: Interdisciplinary theory building in an age of globalization', in Bair J., Frontiers of commodity chain research, Stanford: Stanford University Press.

Sturgeon, T., Van Biesebroeck, J., Gereffi, G. (2008) 'Value Chains, Networks, and Clusters: Reframing the Global Automotive Industry', ITEC Working Paper Series 02-08

Te Velde, D. (2001) 'Policies Towards Foreign Direct Investment in Developing Countries: Emerging Best-Practices and Outstanding Issues', Overseas Development Institute

UNCTAD (2018), "Technology and Innovation Report. Harnessing Frontier Technologies for Sustainable Development", United Nations: Geneva, available at: https://unctad.org/en/PublicationsLibrary/tir2018_en.pdf

UNIDO (2017) Accelerating Clean Energy through Industry 4.0: Manufacturing the next Revolution, Vienna, United Nations Industrial Development Organization

UNIDO (2009), "Impact of the Global Economic and Financial Crisis over the Automotive Industry in Developing Countries", Research and Statistics Branch, Working Paper 16/2009, UNIDO: Vienna

Vacaflores, D.E., (2011) 'Was Latin America correct in relying in foreign direct investment to improve employment rates?', Applied Econometrics and International Development, Vol. 11, pp. $101-122$

Van Biesebroeck, J. and Sturgeon, TJ. (2010) 'Effects of the 2008-09 crisis on the automotive industry in developing countries: a global value chain perspective', in Cattaneo O., Gereffi G., and Staritz C., (eds) Global Value Chains in a Postcrisis World: A Development Perspective. Washington, DC: The World Bank

Winroth M., Bennett D. (2017), "International Production Networks in the Automotive Industry: Drivers and Enablers", paper prepared for the $24^{\text {th }}$ International Conference on Production Research

Wong, W. (2017) 'Automotive Global Value Chain. The Rise of Mega Suppliers', Routledge: London

Xu, B. (2000) 'Multinational enterprises, technology diffusion, and host country productivity', Journal of Development Economics, Vol. 62, pp. 477-493

Zanfei, A. (2012) 'Effects, not Externalities', European Journal of Development Research, 24, pp 8-14, 2012 
Zhang K.H. (2001), "Does Foreign Direct Investment Promote Economic Growth? Evidence from East Asia and Latin America", Contemporary Economic Policy, Vol. 19, pp. $175-185$ 
Tables and Figures

Table 1 and 2: Authors' elaborations on IFR and fDiMarkets data (2005-2014)

\begin{tabular}{|l|r|c|}
\hline \multicolumn{1}{|c|}{ Country } & $\begin{array}{r}\text { Number of } \\
\text { Robots in } \\
\text { Automotive }\end{array}$ & \% tot \\
\hline Japan & 113526 & $21 \%$ \\
\hline US* & 98569 & $18 \%$ \\
\hline Germany & 93082 & $17 \%$ \\
\hline China & 67570 & $12 \%$ \\
\hline South Korea & 58024 & $11 \%$ \\
\hline Italy & 16940 & $3 \%$ \\
\hline France & 15272 & $3 \%$ \\
\hline Spain & 14179 & $3 \%$ \\
\hline United Kingdom & 9989 & $2 \%$ \\
\hline Thailand & 6652 & $1 \%$ \\
\hline Mexico* & 6604 & $1 \%$ \\
\hline Brazil & 5518 & $1 \%$ \\
\hline India & 5180 & $1 \%$ \\
\hline Czech Republic & 5111 & $1 \%$ \\
\hline Canada* & 4627 & $1 \%$ \\
\hline Belgium & 3871 & $1 \%$ \\
\hline Sweden & 3505 & $1 \%$ \\
\hline Slovakia & 3092 & $1 \%$ \\
\hline Turkey & 2578 & less than $1 \%$ \\
\hline Poland & 2495 & less than $1 \%$ \\
\hline Austria & 2041 & less than $1 \%$ \\
\hline Hungary & 1818 & less than $1 \%$ \\
\hline South Africa & 1411 & less than $1 \%$ \\
\hline Portugal & 1172 & less than $1 \%$ \\
\hline Russia & 1129 & less than $1 \%$ \\
\hline Netherlands & 1064 & less than $1 \%$ \\
\hline Argentina & 999 & less than $1 \%$ \\
\hline Romania & 736 & less than $1 \%$ \\
\hline Finland & 459 & less than $1 \%$ \\
\hline Indonesia & 393 & less than $1 \%$ \\
\hline Malaysia & 256 & less than $1 \%$ \\
\hline Australia & 228 & less than $1 \%$ \\
\hline Denmark & 181 & less than $1 \%$ \\
\hline Vietnam & 10 & less than $1 \%$ \\
\hline Total 2014 & 548281 & around $97 \%$ \\
\hline
\end{tabular}

\begin{tabular}{|l|r|c|}
\hline \multicolumn{1}{|c|}{ Country } & $\begin{array}{c}\text { Investment } \\
\text { in auto } \\
\text { FDI_milUS\$ }\end{array}$ & \% tot \\
\hline China & 151774.28 & $24 \%$ \\
\hline Mexico & 63355 & $10 \%$ \\
\hline US & 55030 & $9 \%$ \\
\hline India & 51921.74 & $8 \%$ \\
\hline Brazil & 45657.46 & $7 \%$ \\
\hline Russia & 41887.96 & $7 \%$ \\
\hline Canada & 24824 & $4 \%$ \\
\hline Spain & 21855.52 & $3 \%$ \\
\hline Thailand & 19336.18 & $3 \%$ \\
\hline UK & 17634.03 & $3 \%$ \\
\hline Poland & 16639.42 & $3 \%$ \\
\hline Slovakia & 12839.45 & $2 \%$ \\
\hline Turkey & 11924.78 & $2 \%$ \\
\hline Hungary & 10863.1 & $2 \%$ \\
\hline Czech Republic & 10451.64 & $2 \%$ \\
\hline Romania & 9776.9 & $2 \%$ \\
\hline Indonesia & 9705.49 & $2 \%$ \\
\hline South Korea & 7352.61 & $1 \%$ \\
\hline Germany & 7135.77 & $1 \%$ \\
\hline Argentina & 6983.47 & $1 \%$ \\
\hline South Africa & 6145.99 & $1 \%$ \\
\hline Belgium & 5997.97 & $1 \%$ \\
\hline Australia & 4288.39 & $1 \%$ \\
\hline Austria & 3748.33 & $1 \%$ \\
\hline Portugal & 3576.99 & $1 \%$ \\
\hline Vietnam & 3305.62 & $1 \%$ \\
\hline France & 3029.3 & less than $1 \%$ \\
\hline Malaysia & 1826.01 & less than $1 \%$ \\
\hline Sweden & 1759.2 & less than $1 \%$ \\
\hline Italy & 1705.87 & less than $1 \%$ \\
\hline Netherlands & 1151.74 & less than $1 \%$ \\
\hline Japan & 602.43 & less than $1 \%$ \\
\hline Denmark & 254.3 & less than $1 \%$ \\
\hline Finland & 97.6 & less than $1 \%$ \\
\hline Total 2014 & 634438.54 & around $99 \%$ \\
\hline & & \\
\hline
\end{tabular}


Figure 1: Automotive assembly FDIs and industrial robots

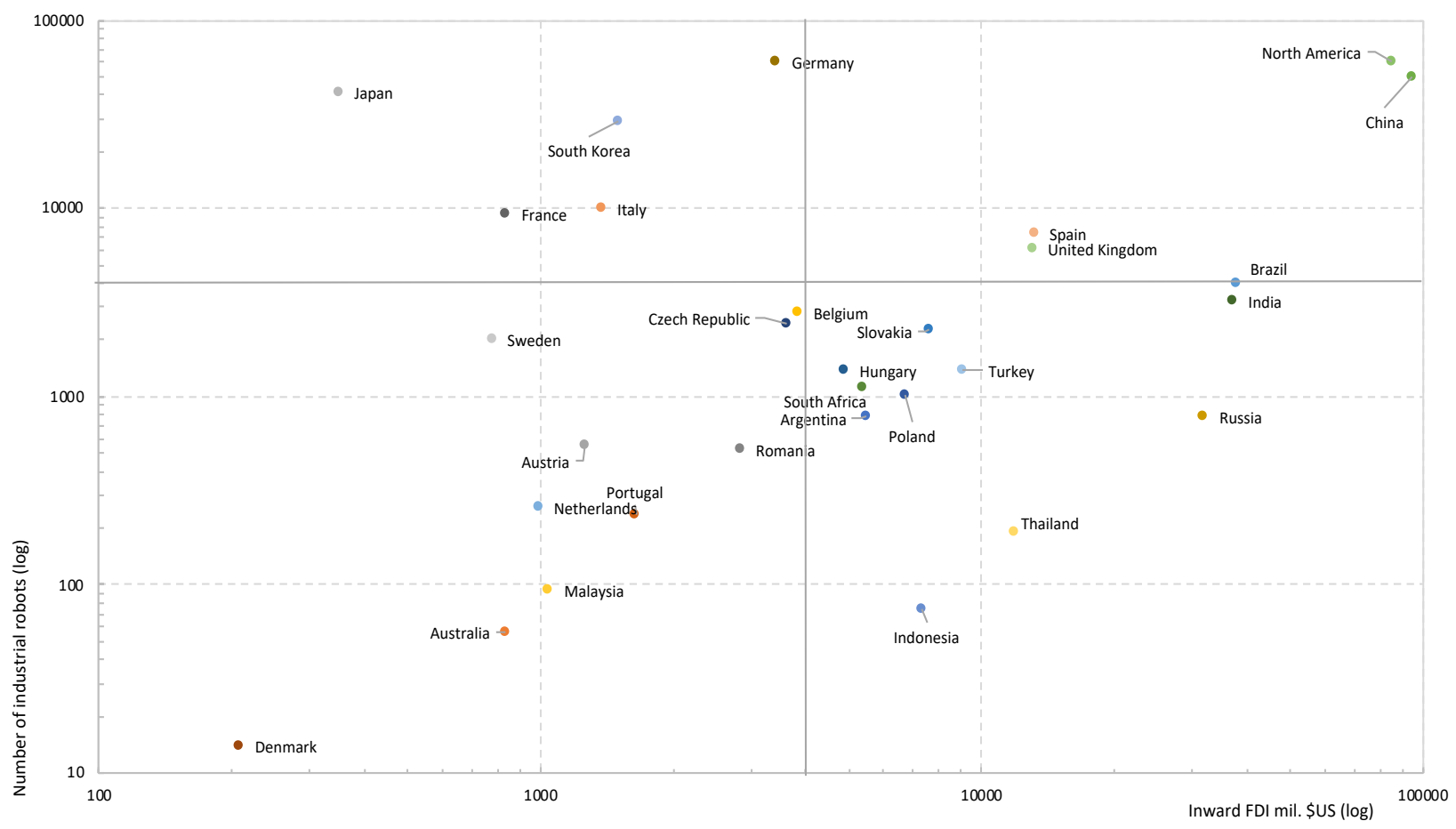

Source: Authors based on IFR and fDi Markets data, 2005-2014 data.

\section{Figure 2: Auto components FDIs and industrial robots}

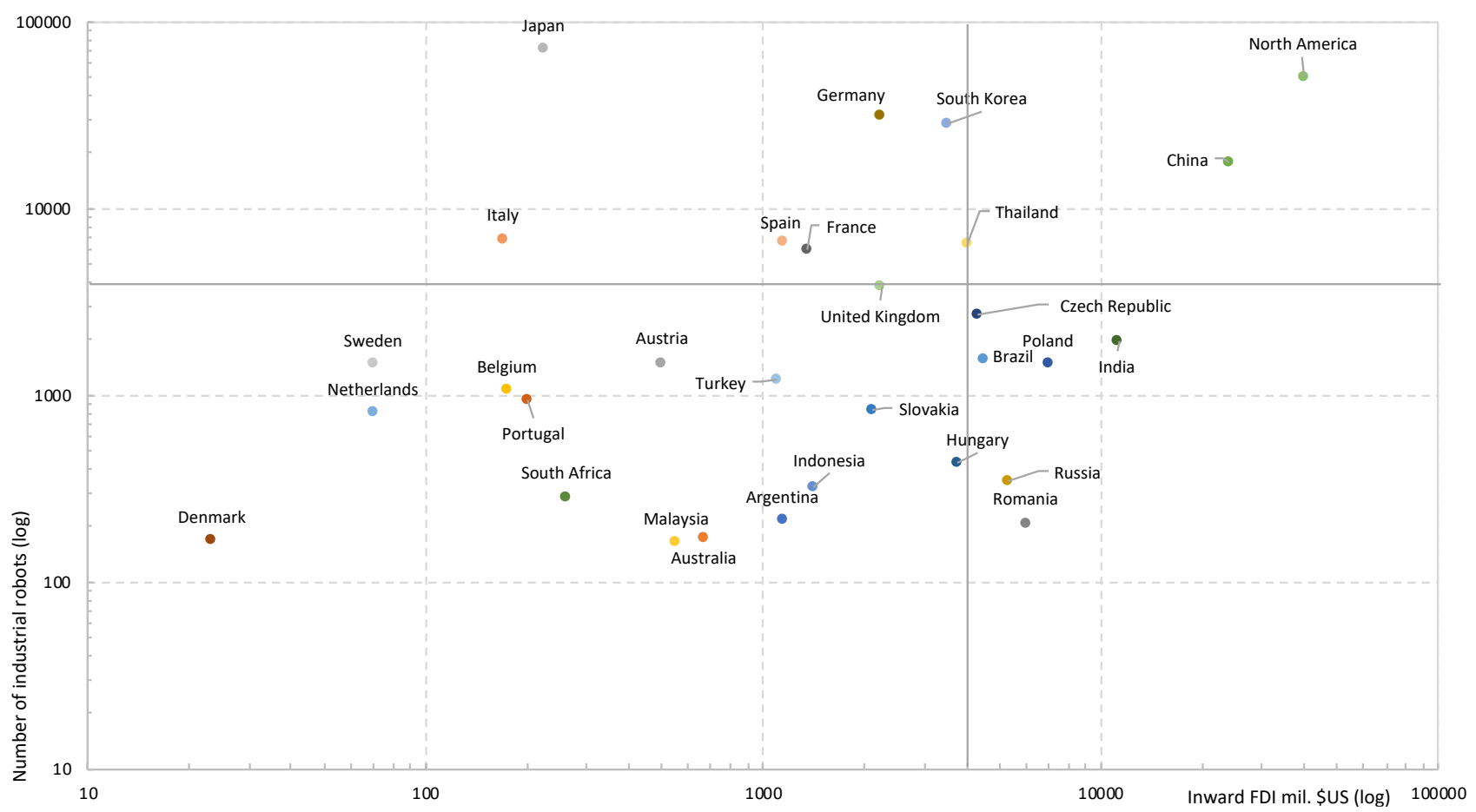

Source: Authors based on IFR and fDi Markets data, 2005-2014 data. 
Figure 3: FDIs and industrial robots' distribution across four segments in time

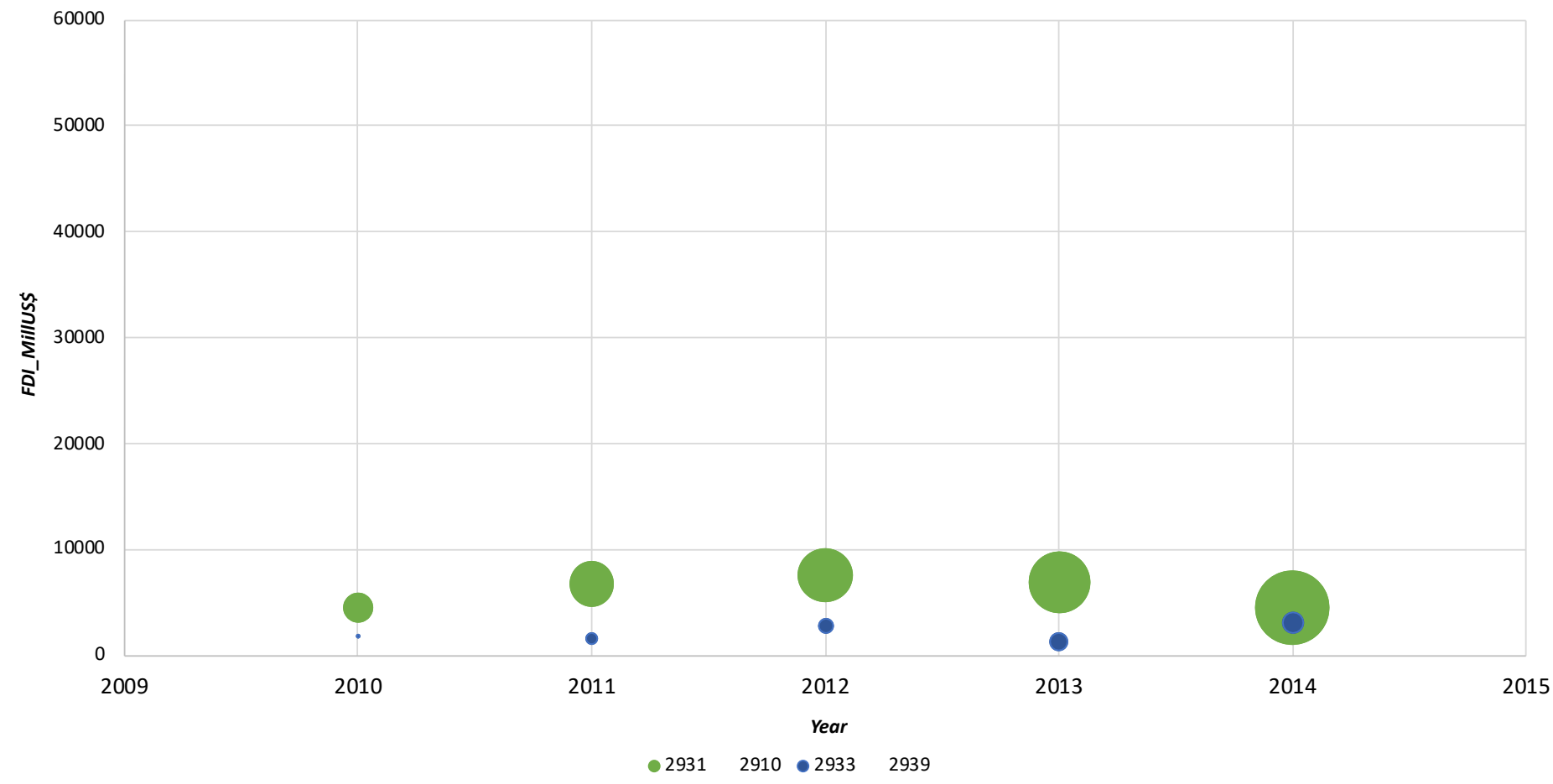

Source: Author based on IFR and fDi Markets data. Vertical axis: FDI intensity; Horizontal axis: year; Size of the bubble: N. of robots (stock); Colour of the bubbles: different subsectors. 
Figure 4: FDIs and industrial robots' distribution across two segments (assembly and parts)

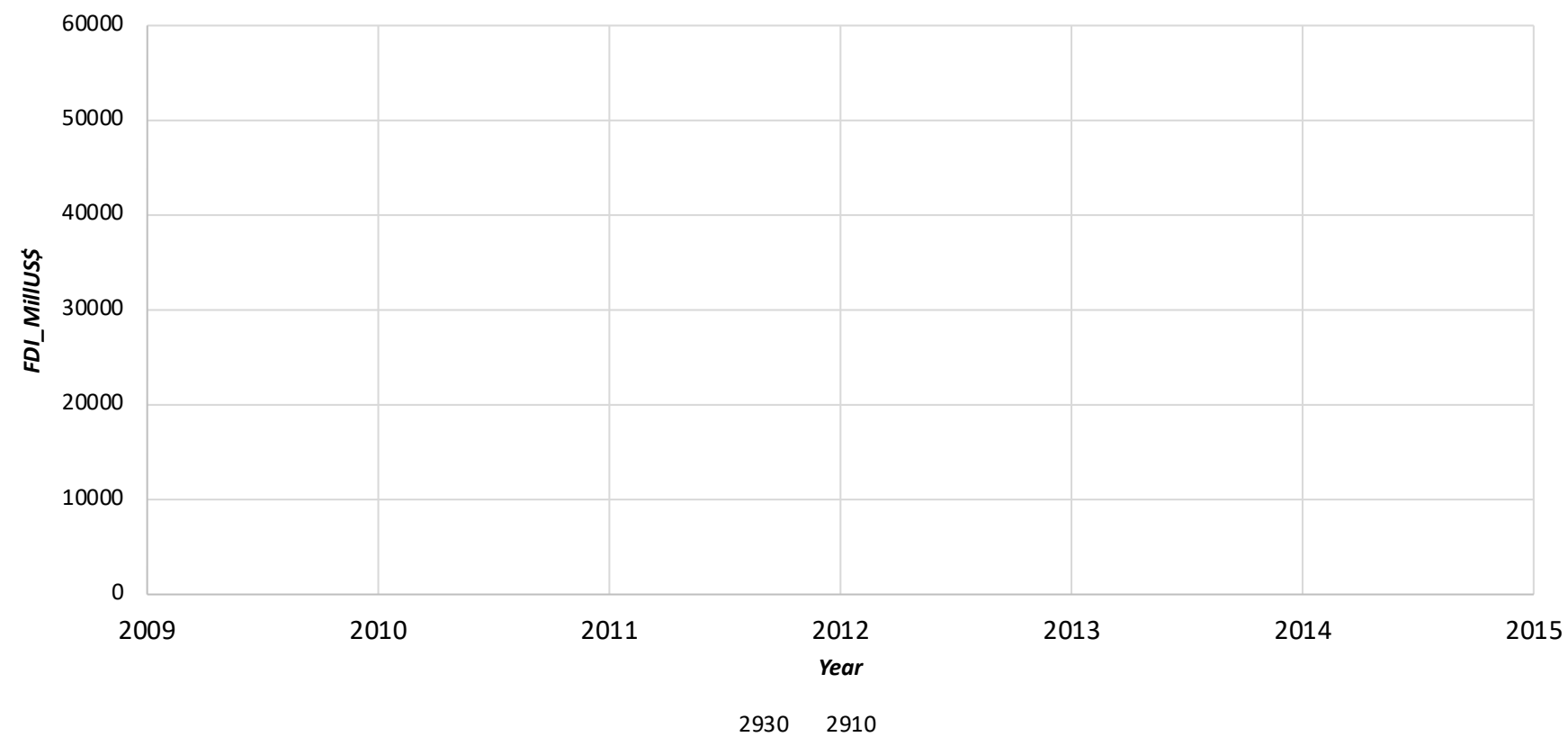

Source: Author based on IFR and fDi Markets data. Vertical axis: FDI intensity; Horizontal axis: year; Size of the bubble: N. of robots (stock); Colour of the bubbles: different subsectors.

Figure 5: FDIs and industrial robots' distribution across three sub-segments of components parts

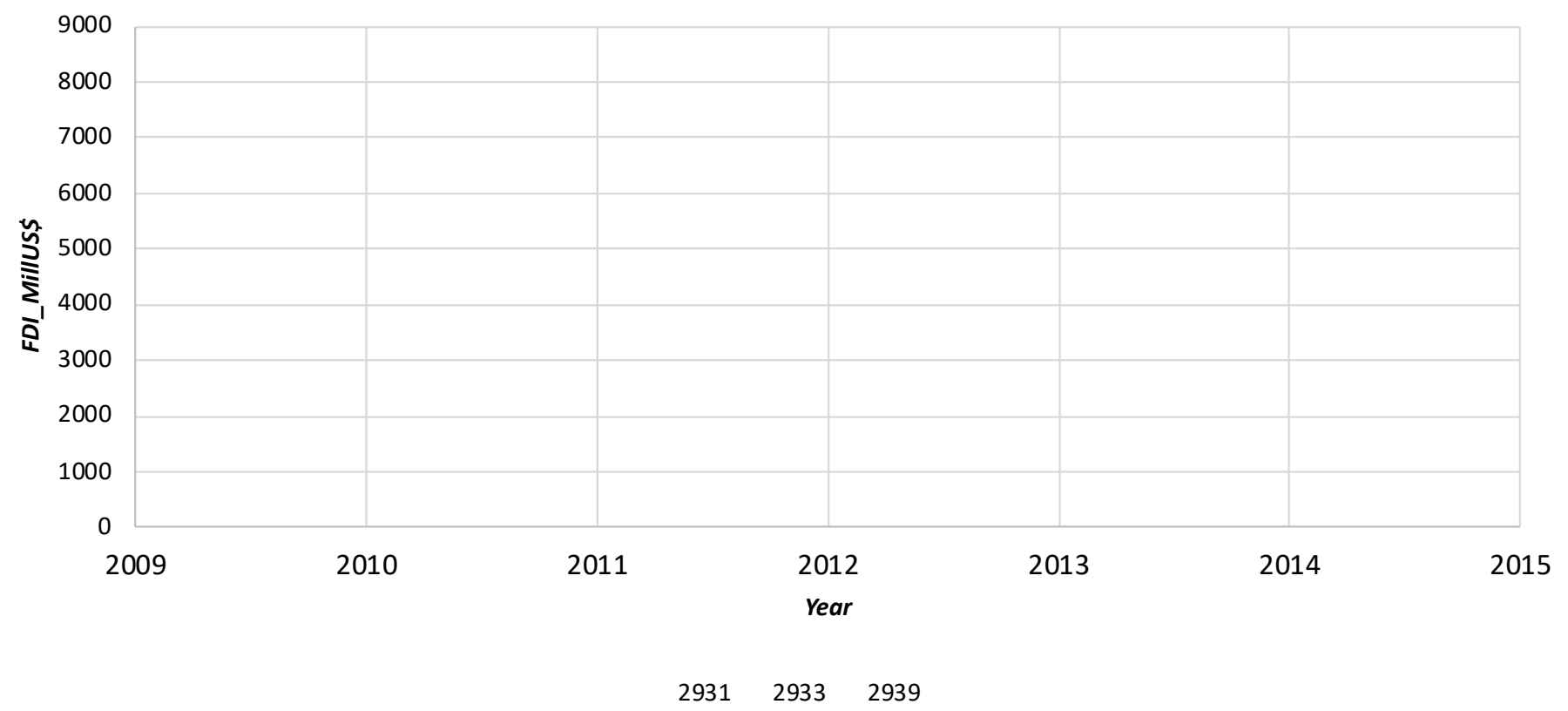

Source: Author based on IFR and fDi Markets data. Vertical axis: FDI intensity; Horizontal axis: year; Size of the bubble: N. of robots (stock); Colour of the bubbles: different subsectors. 
Figure 6: Relation between FDIs and robot's adoption, four-subsectors (country focus)

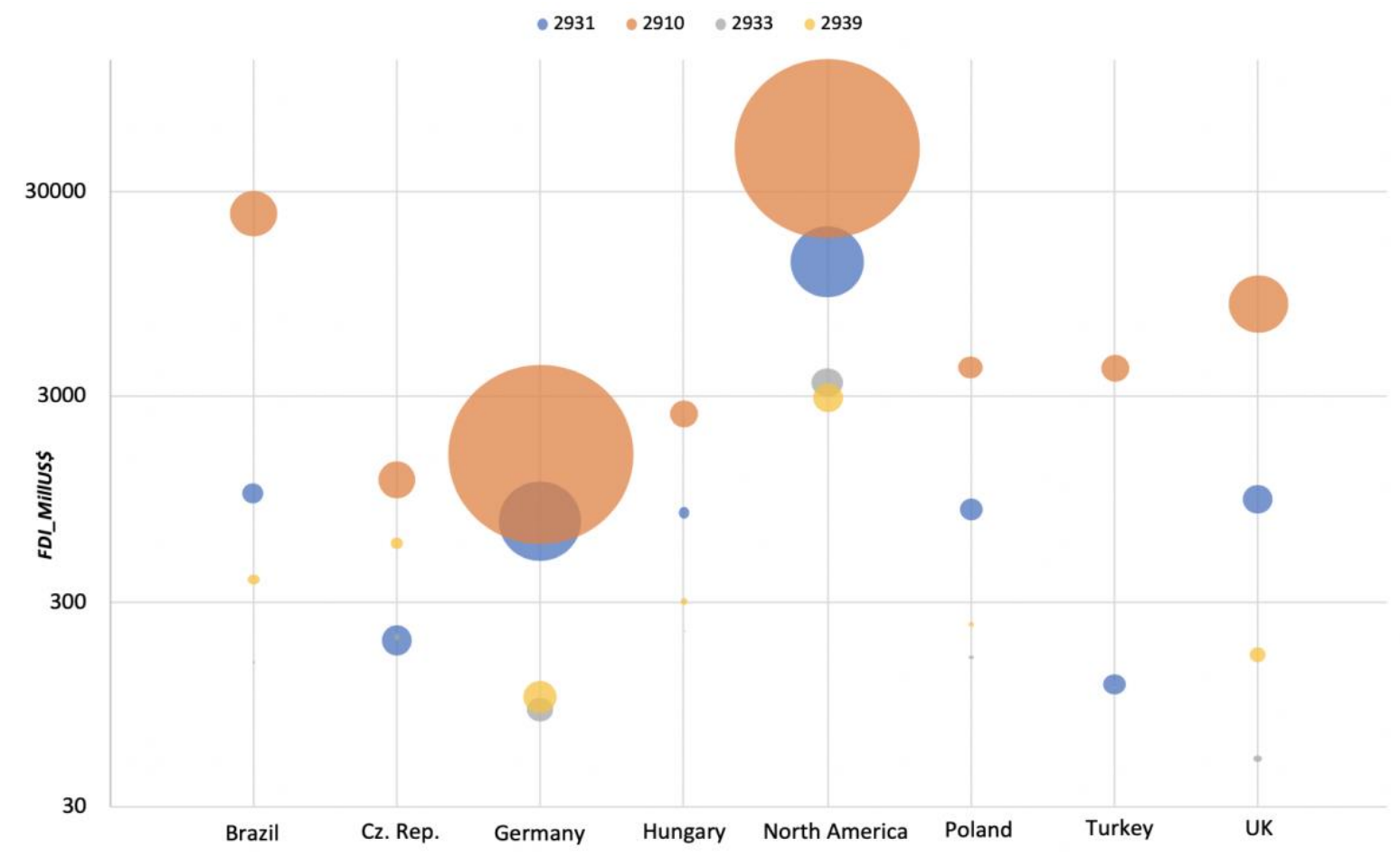

Source: Author based on IFR and fDi Markets data. Vertical axis: FDI intensity; Horizontal axis: selection of countries; Size of the bubble: N. of robots (stock in 2015); Colour of the bubbles: different subsectors. 